\title{
Influence of Urea-Dairy Cattle Dung Fertilizer Combinations on Growth and Production of Mulato Grass (Brachiaria Hybrid cv "Mulato")
}

\author{
Eko Hendarto ${ }^{1}$, Suwarno and Pramono Sudiarto \\ Faculty of Animal Science, University of JenderalSoedirman, Purwokerto, Central Java, Indonesia \\ ${ }^{1}$ corresponding author email : hendarto_e@yahoo.com
}

\begin{abstract}
A research with the aim of obtaining an effective combination pattern of fertilization management was done on mulato grass plants (Brachiaria Hybrid cv "Mulato"). The used fertilizers were of cow dung that serves to maintain the quality of soil and urea that is useful to increase the growth and production of plants. The method used was Completely Randomized Design where the treatments were mixed dairy cattle dung at 10, 17 and 24 tons per hectare per defoliation and urea fertilizer at doses of 75, 150 and $225 \mathrm{~kg}$ per hectare per defoliation. Each treatment was repeated 3 times so that there were 27 plots of research. The parameters studied were plant height, tiller number, leaf number, weed population and fresh forage production. The collected data were analyzed based on Completely Randomized Design, between Orthogonal tested treatment and regression analyzed dose. The results showed that the combined treatment of cow dung as much as 24 tons per hectare per defoliation with urea of $225 \mathrm{~kg}$ per hectare per defoliation (K3U3) showed the best growth and production of Mulato grass, while for the given dosage yielded a linear regression equation.
\end{abstract}

Keywords: Mulato grass, dung cattle dung, urea and plant growth

Abstrak. Penelitian dengan tujuan untuk mendapatkan pola kombinasi manajemen pemupukan yang efektif telah dilakukan terhadap tanaman rumput mulato (Brachiaria Hybrid cv "Mulato"). Digunakan pupuk dari kotoran sapi yang berfungsi untuk mempertahankan kualitas tanah dan urea yang berguna untuk meningkatkan pertum..buhan dan produksi tanaman. Metoda yang digunakan adalah Rancangan Acak Lengkapsedangkan perlakuan yang dicobakan adalah campuran antara kotoran sapi perah pada dosis 10, 17 dan 24 ton per hektar per defoliasi dan pupuk urea pada dosis 75, 150 dan $225 \mathrm{~kg}$ per hektar per defoliasi. Setiap perlakuan diulang sebanyak 3 kali sehingga terdapat 27 petak penelitian. Parameter yang diteliti adalah tinggi tanaman, jumlah tanaman, jumlah daun, populasi gulma dan produksi hijauan segar. Data yang terkumpul dianalisis berdasarkan Rancangan Acak Lengkap, antar perlakuan diuji Orthogonal dan dosis dianalisis regressi. Hasil penelitian memperlihatkan bahwa perlakuan kombinasi pupuk dari kotoran sapi sebanyak 24 ton per hektar per defoliasi dengan urea sebanyak $225 \mathrm{~kg}$ per hektar per defoliasi (K3U3) menunjukkan pertumbuhan dan produksi terbaik dari rumput Mulato, sedangkan untuk dosis yang diberikan menghasilkan persamaan regresi linier.

Kata kunci : Rumput Mulato, kotoran sapi perah, urea dan pertumbuhan tanaman

\section{Introduction}

Forage crops are the main support of ruminant livestock activities as dairy cattle, meat and leather that strongly supports the sustainability of human existence, life and welfare (Hendarto, 2011). Various types of forage crops are introduced to the community to support the progress of ruminant farms. On the other hand, development activities on various cultivation management according to Abdullah, et al. (2011) continues to be done to obtain better productivity and effectiveness. The results of Hendarto and Suwarno (2016) show that the Brachiaria Hybrid grass cV "Mulato" is one of the high potential grass species to be developed and is likely to support the development of ruminant farms. However, on the other hand, the information data related to the Brachiaria Hybrid grass cav "Mulato" has not been widely available, so in the effort to diversify the crops of forage sources, it is desperately needed various information about the cultivation.

One of the factors that contribute to the growth and production of plants according to Barrel et al. (2014) is a factor of soil especially related to soil fertility level. Soil fertility level 
should be maintained for good plant growth which can be done by fertilizing action on the soil. According to Huang, et al. (2004), fertilization is done with the aim of maintaining soil fertility which further growth of plants to be better. Furthermore, it is said by Bhilave, et al. (2013) that organic fertilizers derived from livestock manure can maintain good soil structure and texture, while inorganic fertilizers such as urea, the ingredients are needed to support the growth and production of plants according to the purpose of fertilization.

Hendarto (2005) showed the potential use of manure and urea as a fertilizer that is used jointly or in combination with king grass plants (Pennisetum purpoides). The existence of the benefits of fertilizer action, according to Suharlina and Abdullah (2012) it is deemed necessary to develop a pattern of fertilization that combines the two goals that are for soil conservation and get a better rate of plant growth. According to Wachjar and Kadarisman (2007), manure can be developed from dung cattle dung, while urea fertilizer is used as artificial fertilizer.

\section{Materials and Methods}

Research with Brachiaria Hybrid grass material cv "Mulato" grown with a combination of fertilization between dung cattle dung with urea mixed before use. The experimental method was used for 9 (nine) treatment based on dosage ie dung cattle dung as much as 10 , 17 and 24 tons per hectare per defoliation and 75,150 and $225 \mathrm{~kg}$ urea per hectare per defoliation. Each treatment combination was repeated 3 (three) times. The parameters studied were plant height, number of leaves, number of plants, weed population and fresh forage production on Brachiaria Hybrid grass cv "Mulato". Data obtained, analyzed by Completely Randomized Design, between treatments tested Orthogonal.Untuk dose analyzed by regression.

\section{Results and Discussion}

\section{Condition of Research Sites.}

The research was conducted in the field at Experiment Station of Faculty of Animal Husbandry, Unsoed Purwokerto. Soil samples were analyzed in soil laboratory Agricultural Faculty, Unsoed showed clay texture class of sandy loam soil. Nitrogen content is available as much as 0.108 , phosphor is available as much as $9.81 \mathrm{ppm}$ P2O5, while the soil acidity degree is 6.10 which shows neutral.

Structure of the land is sufficient to support the growth of plants including grass plants with the physical properties of the soil that is easily processed. Such conditions give meaning which aids the soil. The degree of acidity $(\mathrm{pH})$ of the soil of the study sites of 6.10 according to Rinsema (1989) shows in an excellent category for plant growth. The availability of nutrients is closely related to the degree of acidity. In relation to the degree value of the acidity shown, it shows that the location of the study on the condition of nutrient availability that supports growth for the plant.

Structure of the land is sufficient to support the growth of plants including grass plants with the physical properties of the soil that is easily processed. Such conditions give meaning which aids the soil. The degree of acidity $(\mathrm{pH})$ of the soil of the study sites of 6.10 according to Rinsema (1989) shows in an excellent category for plant growth. The availability of nutrients is closely related to the degree of acidity. In relation to the degree value of the acidity shown, it shows that the location of the study on the condition of nutrient availability that supports growth for the plant.

Based on the above conditions it shows that the research sites support to obtain a good growth of Brachiaria Hybrid grass cv "Mulato" grass. Molato grass plant as a forage source plant is expected to have a wide tolerance of environmental conditions and can produce good growth and production. 
Height of Brachiaria Hybrid cv "Mulato"Grass.

The average height of the plant is $72.8 \mathrm{~cm}$ in the range between $63.90-84.33 \mathrm{~cm}$ shows that the average height of the Brachiaria Hybrid grass cv "Mulato" given the various treatments, is present in the short size as a superior feed plant. Table 1 shows that in addition of doses for each type of fertilizer, it shows the addition of plant height. Higher doses indicate higher plant height as well. This is in accordance with the opinion of Taufika (2011), that at each addition of nutrient doses into the soil to some extent, will have an impact on growth and plant production.

At the given treatment, showed different results. Treatment with each of the highest doses (K3U3) resulted in the highest crop height $(84.33 \mathrm{~cm})$, while at the lowest (K1U1) was at the shortest size $(63.90 \mathrm{~cm})$. The effect of fertilizer from both dairy cattle dung and urea, will provide a response to plant growth including the height of the plant. Fertilizer from cow dung is also useful for preservation of soil while urea spur growth of plants. Brachiaria Hybrid grass plants cv "Mulato", has received a real influence from a combination of cow manure and urea.

Fertilizer from cow dung, when it is fertilized to the soil element before it can be utilized by plants waiting for the decomposition process while in urea fertilizer, haranya element can be directly utilized the plant. Through a combination pattern between cow dung and urea has been able to provide a joint effect. In this regard, the application of cow manure and urea together can be developed to obtain a positive effect collectively, that is, the acquisition of soil with organic fertilizer and growth and crop production can be expected together.

Based on the results of analysis of variance indicated that the treatment given and the dosage of pupukidak influence $(P>0,05)$ to the height of grass plant Brachiaria Hybrid cV "Mulato". Although the average yield of plant height is different, it can be said that the treatment given can be considered uniform. Such basically the combination of dosage dosage of 24 tons per hectare per defoliation and urea of $225 \mathrm{~kg}$ per hectare per defoliation can be applied to Mulatograss.

Table 1. Mean values of some aspects of performances of Mulato grass under various fertilizer combinations.

\begin{tabular}{|c|c|c|c|c|c|c|c|}
\hline Notation & $\begin{array}{c}\text { Cow dung } \\
\text { (Ton/ha/def) } \\
\text { (K) }\end{array}$ & $\begin{array}{c}\text { Urea } \\
\text { (Kg/ha/def) } \\
\text { (U) }\end{array}$ & $\begin{array}{c}\text { Plant } \\
\text { height }(\mathrm{cm})\end{array}$ & $\begin{array}{l}\text { Number of } \\
\text { plant(stem) }\end{array}$ & $\begin{array}{c}\text { Number of } \\
\text { leaflet(sheet) }\end{array}$ & $\begin{array}{c}\text { Weed } \\
\text { value(Nilai) }\end{array}$ & $\begin{array}{c}\text { Fresh } \\
\text { matter } \\
\text { yield } \\
\left(\mathrm{Kg} / \mathrm{m}^{2}\right) \\
\end{array}$ \\
\hline K1U1 & 10 & 75 & 63.90 & 10.33 & 46.90 & $4.33^{a}$ & $0.878^{d}$ \\
\hline K1U2 & 10 & 150 & 64.80 & 11.00 & 48.66 & $3.67^{a}$ & $0.956^{d}$ \\
\hline K1U3 & 10 & 225 & 73.43 & 11.00 & 57.77 & $2.33^{a}$ & $1.144^{d}$ \\
\hline K2U1 & 17 & 75 & 72.13 & 10.33 & 50.77 & $4.33^{b}$ & $0.933^{\mathrm{e}}$ \\
\hline $\mathrm{K} 2 \mathrm{U} 2$ & 17 & 150 & 72.53 & 11.00 & 49.87 & $3.33^{b}$ & $1.144^{\mathrm{e}}$ \\
\hline K2U3 & 17 & 225 & 79.57 & 11.33 & 55.33 & $2.00^{\mathrm{b}}$ & $1.167^{\mathrm{e}}$ \\
\hline K3U1 & 24 & 75 & 70.30 & 12.00 & 56.90 & $3.66^{C}$ & $1.133^{f}$ \\
\hline K3U2 & 24 & 150 & 73.47 & 13.00 & 57.77 & $2.33^{C}$ & $1.333^{f}$ \\
\hline K3U3 & 24 & 225 & 84.33 & 14.33 & 59.03 & $1.33^{C}$ & $1.500^{f}$ \\
\hline \multicolumn{3}{|c|}{ Mean } & 72.80 & 11.60 & 53.67 & 3.04 & 1.13 \\
\hline
\end{tabular}




\section{Number of plant.}

The number of Mulato grass plants due to the combined treatment of sapiperah and urea manure, at an average of 11.6 pieces per clump in second defoliation. The highest number was found in the treatment of K3U3 (14.33 fruit plants) and the least in treatment K1U1 (10.33 crops). According to Gordeyasemas, et al. (2007), stated that dung cow manure with macro nutrients, made possible after the addition of nitrogen from urea fertilizer in the form available to the crops, has encouraged the growth of Mulato grass plant growth, including the number of plant parameters.Aminudin and Hendarto (2000) growth-promoting elements such as nitrogen found in urea fertilizers have been able to support plant growth, including the number of Mulato grass plants.

The result showed that the treatment and dosage of fertilizer from sapiperah dung were very significant $(P<0.01)$, and urea dose did not affect $(P>0,05)$, to the number of Mulato grass plants. Provision of cow manure differs significantly more significantly $(P<0.01)$ than urea fertilizer. Dosage dung fertilizer dosage yielded very real linear equation $(P<0,01)$ ie $Y=$ $8,70,17 \times$ (Figure 1).

The results of Hendarto and Suwarno (2014) study that the addition of combined dosage of organic and inorganic fertilizer on Nevalensis grass will increase plant growth. Mulato grass plants are able to produce a large number of plants, according to Xiangyang, et al. (2011) will be more on the addition of nitrogen elements supplied from dairy cattle manure that has undergone decomposition. The existence of growth is marked by the addition of the number of plants according to Abdullah, et al. (2011), will have an effect on grass production, as well as on the quality and quantity and continuity of good production. Ferreira, et al, (2015), adding that the technical pattern of crop management with fertilization is essentially an important factor in efforts to generate growth and crop production.

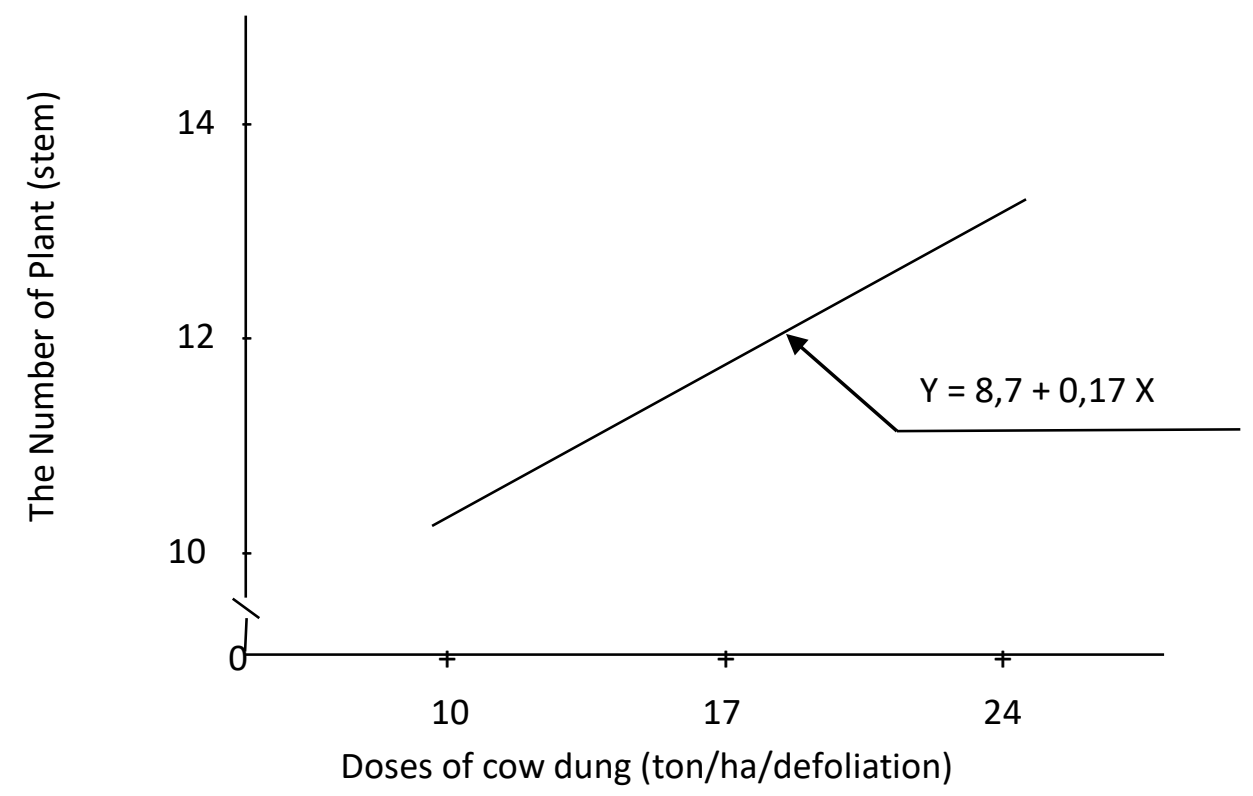

Figure 1. The relationship between dose of dung cow manure with the average number of Mulato grass plants. 
The results of Hendarto and Suwarno (2014) study that the addition of combined dosage of organic and inorganic fertilizer on grass will increase plant growth. Mulato grass plants are able to produce a large number of plants, according to Xiangyang, et al. (2011) will be more on the addition of nitrogen elements supplied from dairy cattle manure that has undergone decomposition. The existence of growth according to Abdullah, et al. (2011), will have an effect on grass production, as well as on the quality and quantity and continuity of good production. Ferreira, et al, (2015), adding that the technical pattern of crop management with fertilization is essentially an important factor in efforts to generate growth and crop production.

Being an advantage in the use of urea combined with fertilizer from dairy cattle dung that urea with nitrogen nutrient content alone has been encouraging for vegetative growth of plants. At the time the plant requires nutrients, according to Xiangyang et al. (2011) nutrients from urea are available. Meanwhile, on the use of fertilizer from dung cow dung, when the nutrients it contains in the decomposition process conditions, according to Slamet et al. (2005), plants have utilized nutrients derived from urea fertilizers, so that until the nutrient stage of urea fertilizer runs out, according to Marpaung et al. (2014) the growth can still be continued towards generative growth using nutrients derived from fertilizer from dairy cattle dung.

\section{Number of Grass Leaves}

The average number of leaves of Brachiaria Hybrid grass cav "Mulato" on the effect of fertilizer combination combination of dung cattle dung mixed with urea fertilizer as much as 53.67 pieces of leaf per hill. Such amounts are in the range between 46.9 - 59.3 pieces of leaf. The amount will support the fresh forage production obtained at each treatment. Provision of cow dung as much as 24 tons per hectare per defoliation mixed with urea $225 \mathrm{~kg}$ per hectare per defoliation has shown the highest number of leaves per mulburn grass plant. The results of research Hendarto, et al. (2014) also reported similar conditions applied to the grasses of Setaria, Bengal and Greenpanic that the provision of a combination of organic and inorganic fertilizers can increase plant growth. Added by Hendarto (2012) that nutrient content that has been decomposed from manure such as dung cattle dung has an effect on plant growth, including the number of leaves of the developed crop (Mulato grass), while Hendarto (2005) adds that the nitrogen content of urea integrated in combined use has featured plant growth rates including Brachiaria Hybrid grass cv "Mulato". The nitrogen content that is already available to plants from urea has created the condition (Aminudin and Hendarto, 2000). When compared to other plants and based on the appearance in the field, the number of Grachiaria Hybrid grass leaves cv "Mulato" can still be improved, however the application of fertilizer combination strategy can still be developed further with other dosage or fertilization pattern. According to Hendarto (2011) various management strategies including fertilization can be done to support the sustainability of human existence, life and wellbeing.

The result of variance analysis showed that the treatment, dose of fertilizer and its interaction had no effect $(P>0,05)$ on the number of leaves per clump of plants from Brachiaria Hybrid grass cv "Mulato". Although there is a difference from each treatment, but basically it does not affect the leaf number parameters. It shows that all given treatments are considered uniform, will show relatively similar conditions. However, Georgiadis (2007) adds that in the process of photosynthesis of plants and energy generation can be done because plants use nitrogen from the soil, the energy is used for plant growth, such as to 
increase the number of leaves from each clump of plants.

\section{Population Level of Weed}

Weeds are not expected in cultivation of crops including feed crops. This happens because weeds will absorb soil nutrients, thus harming the main plant (Min et al., 2012). The existence of weed populations on the expanse of cultivation of feed crops is also influential on the growth of feed plants (Sinaga, 2007). The results showed that the average weed population level on Mulato grass cultivation, showed a value of 3.04 indicating that the growth of gulmanya quite a lot and grow under Mulato grass plants. Treat combination of K1U1 and K2U1 with the most weed growth (weed population value $=4,33$ ), whereas the combination of treatment K3U3 of the population value of the gulman is slightly 1.33. These conditions show that on the growth of a good Mulato grass, it has prevented the weeds from growing. The assessment range is from 1 to 5 (from very little to very many).Mulato's fertile grass plots have blocked the entry of sunlight into the growth of weeds under the Mulato plant, which according to Maduana (2009) causes useless growth of weeds and causes weeds to become small. In contrast to patches of poor Mulato grass growth, there is evidence of weed growth at the population level.

The result of variance analysis showed that the treatment and dosage of fertilizer from dung cow dung had a high significant effect ( $P$ $<0.01)$ while in urea fertilizer had significant effect $(P<0.01)$ on growth value of weed populations from Mulato grass. The provision of dairy cow manure is very different $(P<0.01)$ than urea fertilizer. The dosage of cow dung produced a very significant linear relationship ( $P$ $<0.01$ ) ie $Y=4.247-0.071 \mathrm{X}$ indicating that dung cow dung fertilization up to 24 tonsper hectare per defoliation still decreases the growth of weed value. Similarly with urea dose, there is a very real linear relationship $(P<0.01)$ ie $Y=4.045-00067 X$ which shows urea fertilization up to $225 \mathrm{~kg}$ per hectare per defoliation also contributes to the decline in the growth value of Mulato grass weeds.

Slamet, et al. (2005), states that livestock manure and urea have different roles associated with soil and crop conditions. Alfaro and Salazar (2008) added that the leafy plants cause the decomposition process to be slower, it may affect weed conditions. Salendu et al. (2012) adds that the use of dairy cow manure combined with urea fertilizer, according to Hendarto (2005) has a positive impact on plant growth. In upright plants such as Mulato grass will produce good growth, it can suppress the growth of weeds thereby reducing weed populations in plant plots.

If associated with the height of the plant and the number of leaves of mulato grass indicates the suitability of the condition with the value of the population of weeds produced. Mulato grass which has high plantn high and the number of leaves is high, low gulman population value, whereas plants with high plant size is low and the number of leaves is low, high gulmanya population value. This is in accordance with the results of research Hendarto and Suwarno (2017) on Nevalensis grass plants.

\section{Fresh matter production}

Mulato fresh forage production is flat at 1.13 $\mathrm{kg}$ per square meter in the range of 0.878 $1,500 \mathrm{~kg}$. The average of production obtained by Mulato grass due to the influence of dosage combination of dung fertilizer with urea is high in the 2nd defoliation harvest. The highest production is found in the treatment of $\mathrm{K} 3 \mathrm{U} 3$ which is the combination of duck treatment of cow dung as much as 24ton per hectare per defoliation with urea fertilizer at dose as much as $225 \mathrm{~kg}$ per hectare that is $1,500 \mathrm{~kg}$ per square meter. 


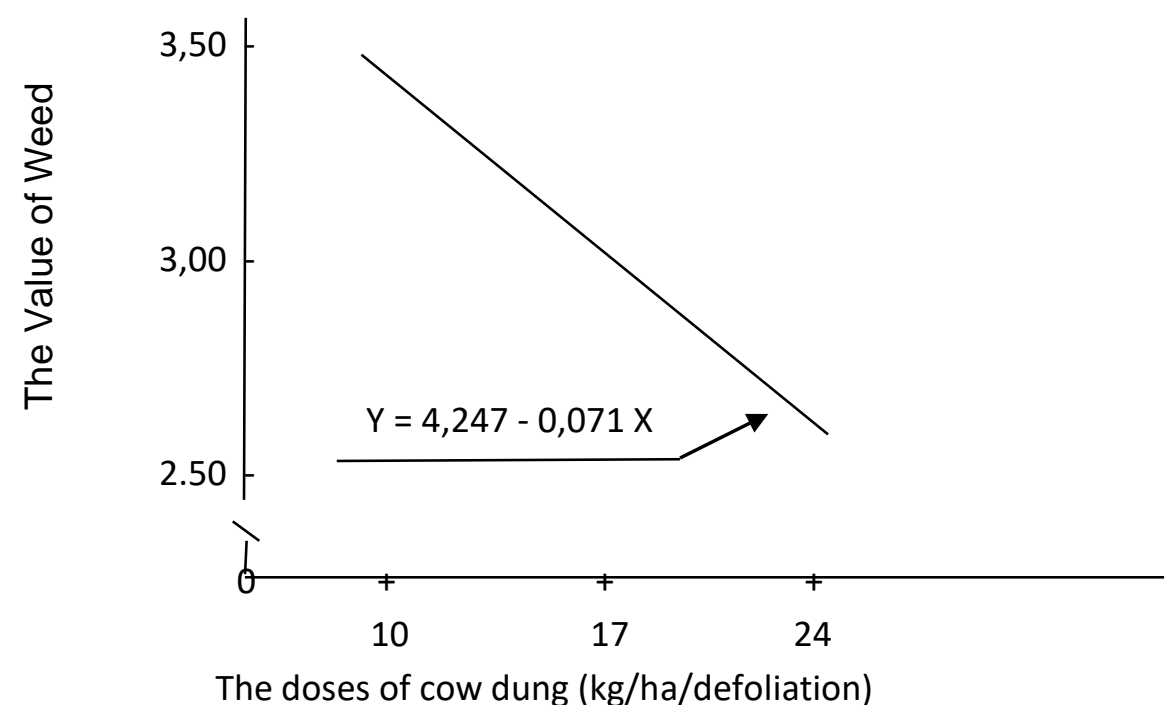

Figure 2. The relationship between dosage of dung cow manure with the average value of Mulato grass mulching population.

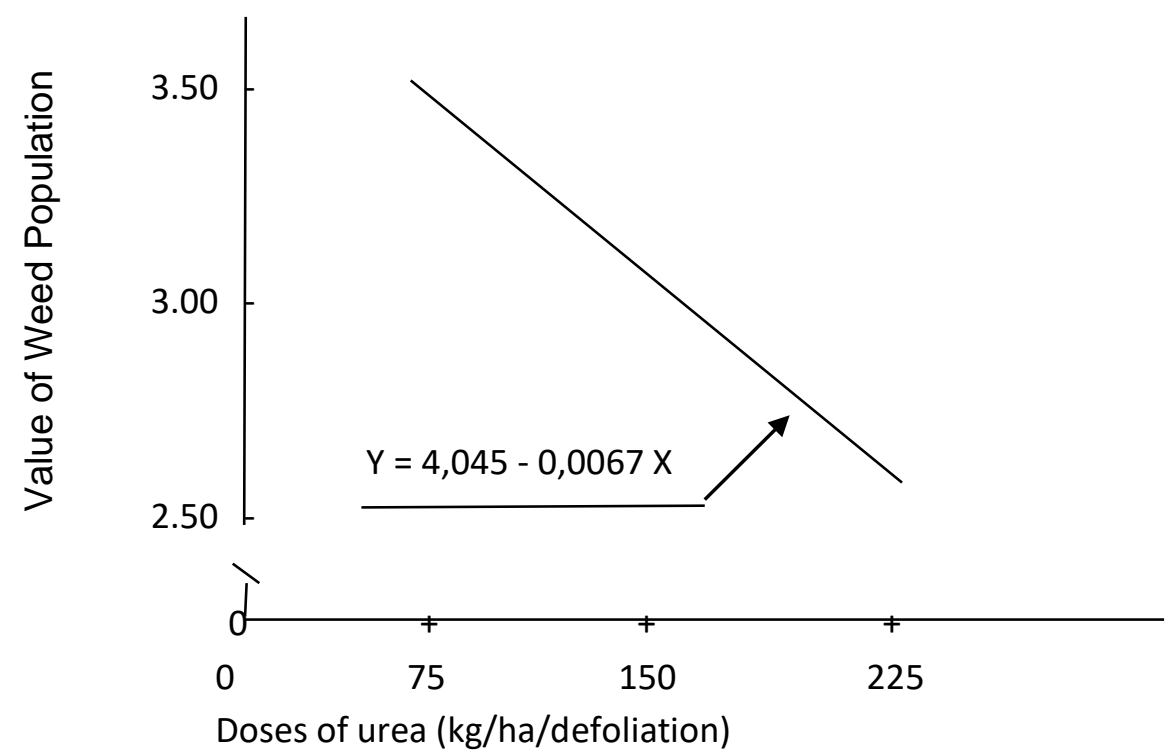

Figure 3. Relationship between the dose of urea fertilizer with the average weed population value on Mulato grass plants.

If the results of research applied in the field illustrate that MulatoMulaca fresh grass production can become a proponent of ruminant livestock business. There is a fresh forage production of 101,700 kg per hectare per year if harvested 9 times and can provide livestock tamping capacity of 8 livestock units (UT) . The level of production, able to provide a good capacity in ruminants farm business. The results of production shown, according to Aminudin and Hendarto (2000) are relatively in accordance with genetic quality which shows that the genetic aspects of the plant can not be lost due to the given treatment factor.

In the fertilizer of dairy cow manure, it contains nitrogenous nutrients, as well as in urea fertilizers that serve to stimulate overall plant growth including support for fresh forage production (Rahman, et al., 2013) Added by Bhilave, et al. (2013) that the use of cow dung manure in an effort to utilize organic waste can potentially be applied in the field. The weakness 
found in dairy cow manure according to Marpaung, et al. (2014) is that the ingredients are not yet available for plants because they still require a decomposition process. The process of decomposition according to Hanolo (1997), causing delays in the availability of nutrients for plants.

The results of the analysis show that the treatment and dosage of dung cattle dung and urea fertilizer have a very real effect $(P<0.01)$, on the production of Mualato grass forage. Provision of dung fertilizer is significantly different $(P<0.01)$ than that of urea fertilizer. The dose of cow dung is very significant ( $P$ $<0.01$ ) ie $Y=2.20 .07 \times$ (per plot $=3$ square meters) indicating that the fertilization of cow dung up to a dose of 24 tons per hectare per defoliation still provides an increase in fresh forage production. Similarly, with urea dose, there is a very real linear relationship $(P<0.01)$ that is $Y=2.40 .0066 \times$ (per plot $=3$ square meters) which also shows that urea fertilization up to a dose of $225 \mathrm{~kg}$ per hectare per defoliation shows an increase in Mulato's grass production.

Wijitphan et al. (2009) states that nitrogen nutrients are able to give effect to the production on plants. Nutrient nutrients are found in organic fertilizer from cow dung and inorganic from urea.Added by Rahman, et al., (2013) that the element of nitrogen nutrients serves to stimulate the growth and production of plants. Based on the results of the research, it is shown that the higher dosage of dairy cow manure up to 24 tons per hectare per defoliation and urea fertilizer up to $225 \mathrm{~kg}$ per hectare per defoliation has provided an increase in Mulato grass growth and production. Although there is a very significant effect $(P<0.01)$ from the treatment of the parameters studied, but basically there is a combination treatment of fertilizer which can be recommended to be applied that is the combination treatment of cow dung manure as much as 24 tons per hectare per defoliation with fertilizer urea at a dose of $225 \mathrm{~kg}$ per hectare per defoliation.

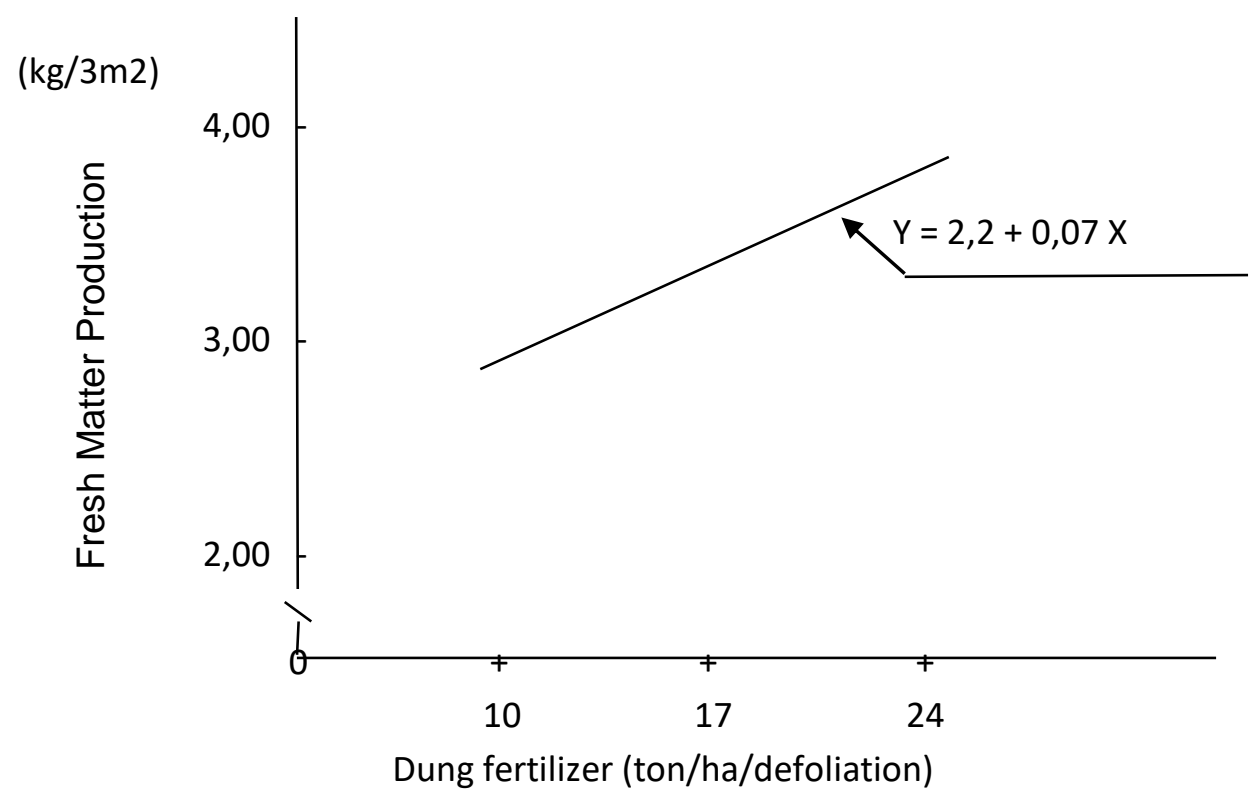

Figure 4. Relationship between dosage dung fertilizer dung with the average production of fresh grass Mulato grass. 


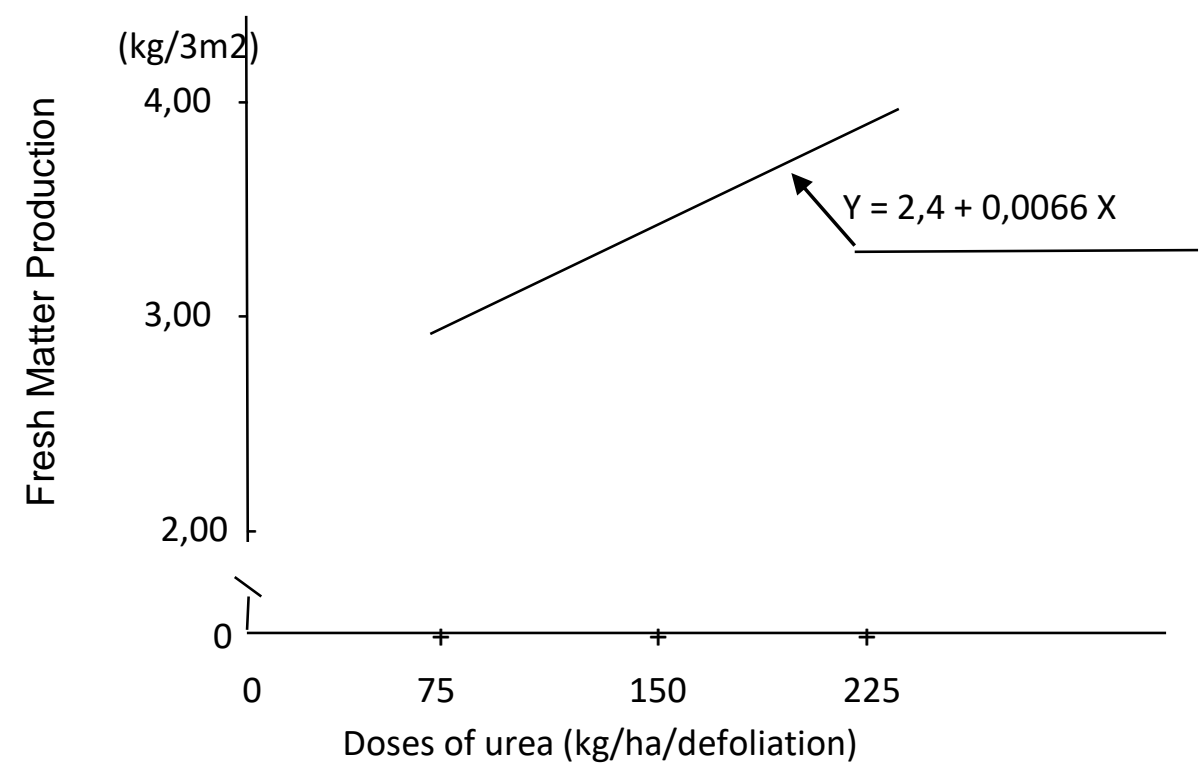

Figure 5. Relationship between the dose of urea fertilizer with the average value of Mulato's fresh grass green production.

Added by Astuti (2005) when the nutrient elements of organic fertilizer have arrived at the time available, the plant has reached the stage of generative growth that does not require much nutrients in large quantities. It is possible that the nutrient benefit of organic fertilizer is obtained on the growth of the next grass plants after harvesting, so that based on Hendarto (2005) research is necessary to combine with anorganic fertilizers such as urea whose nitrogen element is ready to be absorbed by plants by mixing it

\section{Conclusions}

Based on the discussion that has been done, it can be concluded that the application of dung cattle dung fertilizer mixed with urea on Brachiaria Hybrid grass cv "Mulato" showed the application of dairy cow manure up to a dose of 24 tons per hectare per defoliation mixed with urea to a dose of $225 \mathrm{~kg}$ per hectare per defoliation can provide good plant growth and grass production.

\section{References}

Abdullah, L. D.D.S. Budhiedan A.D. Lubis, 2011. Pengaruh Aplikasi Urin Kambing dan Pupuk Cair Organik Komersial terhadap Beberapa Parameter
Agronomi pada Tanaman Pakan Indigofera Sp. Pastura. Vol. 1 (1): $5-8$.

Alfaro, M. and F. Salazar. 2008. Livestock Production and Diffuse Pollution in a Volcanic Soil. Journal of Soil Science Plant Nutrition 8 (2): 1-8.

Aminudin, S. dan E. Hendarto. 2000. Ilmu Tanaman Pakan, Buku Ajar. Fakultas Peternakan Universitas Jenderal Soedirman, Purwokerto.

Astuti, A. 2005. Aktivitas Proses Dekomposisi Berbagai Bahan Organik dengan Aktivator Alami dan Buatan. Jurnal IImu Pertanian. 13 (2) : 92 104

Bhilave, M.P., S.B. Nadaf, S.V. Bhosale and V.B. Nalawede, 2013. Nutrition analysis of plant formulated feeds. Research Journal of Agricultural Sciences. Vol. 4 (4): 480-483

Borrel, A.K., J.E. Mullet, B.G. Jaegli, E.J. Oosterom, G.L. Hammer, P.E. Klein, and D.R. Jordan, 2014. Drought Adaptation of Stay-Green Shorgum is Associated with Canopy Develompemnt, Leaf Anatomy, Root Growth, and Water Uptake. Journal of Experimental Botany Vol. 65, No. 21, pp.6251-6263.

Ferreira, J.F.S., M.V. Cornacchione, X. Liu and D.L. Suarez, 2015. Nutritient Composition, Forage Parameters, Antioxidant Capacity of Alfalfa (Medicago sativa, L.) in Response to Saline Irrigation Water.Journal Agriculture. Vol. 5: 577597

Georgiadis, N. J., 2007. Savvana Herbivore Dynamics In A Livestock-Dominated Landscape. II : Ecological, Conservation, And Management 
Implication Of Predator Restoration. Journal of Biological Conservation 137 (2007).

Gordeyasemas I.K., R. Hartanto dan W.D. Prastiwi, 2007. Proyeksi Daya Dukung Pakan Limbah Tanaman Pangan Untuk Ternak Ruminansia di Jawa Tengah. Jurnal Pengembangan Peternakan Tropis. Journal of The Indonesian Tropical Animal Agriculture. 32 (4) : 23-29.

Hanolo, W. 1997. Tanggapan Tanaman Selada dan Sawi terhadap Dosis dan Cara Pemberian Pupuk Cair Stimulan. Jurnal Agrotropika Vol. 1 (1): 25 29

Hendarto E, 2005. Pengaruh Kombinasi Pupuk Organik dan Dosis Urea terhadap Kualitas Visual dan Produksi Rumput Raja (Pennisetumpurpoides). Jurnal Pembangunan Perdesaan. Vol 5 No 2. Lembaga Penelitian Universitas Jenderal Soedirman. Purwokerto.

Hendarto, E. 2011. Dimensi Lingkungan Tata Ruang Peternakan Sapi Perah Rakyat Di Kabupaten Banyumas, Provinsi Jawa Tengah. Disertasi. Program Pascasarjana. Universtas Diponegoro. Semarang

Hendarto, E., 2012. Penampilan Aspek Agronomi Rumput Gajah (Pennisetum purpureum) Di Bawah Pengaruh Berbagai Jenis Dan Dosis Pupuk Organik Dan Anorganik. Prosiding Seminar Nasional Peran Pertanian Dalam Menunjang Ketahanan Pangan dan Energi Untuk Memperkuat Ekonomi Nasional Berbasis Sumberdaya Lokal. Fakultas Pertanian. Universitas Jenderal Soedirman. Purwokerto.

Hendarto, E. Dan Suwarno, 2013. Pengaruh Kombinasi Antara Pupuk Kandang dan Urea pada Tampilan Aspek Pertumbuhan Tanaman Rumput Raja, Pemanenan Defoliasi Ke Empat. Bionatura. Journal of Life and Physical Sciences. Vol. 15 (2): $86-91$.

Hendarto, E., Suwarno, P. Sudiarto dan S. Anwar, 2014. Pengaruh Berbagai Tingkat Kombinasi Urea dan Kotoran Sapi Perah Pada Tinggi Tanaman dan Produksi Segar Berbagai Tanaman Pakan Defoliasi Pertama. Prosiding Seminar Nasional Pengelolaan Sumberdaya Alam dan Lingkungan. Program Pascasarjana. Universitas Diponegoro. Semarang.

Hendarto, E, and Suwarno, 2017.Effect of Traditional-Market -Waste Liquid Organic Fertilizer on the Growth Aspects of Setaria. International Seminar On "The Future of Energy Reserves and Utilizations". Program Pascasarjana, UniversitasDiponegoro, Semarang.
Huang, Z.A., D.A. Jiang, Y, Yang, Y.W. Sun and S.H. Jin. 2004. Effects of Nitrogen Deficiency on Gas Exchange, Chlorophyll Fluorescence, and Antioxidant Enzymes in Leaves of Rice Plants. Photosynthetica. Vol. 42 (3): 357-364.

Marpaung, A.E., B. Karodan R. Tarigan, 2014. Pemanfaatan Pupuk Organik Cair dan Teknik Penanaman Dalam Peningkatan Pertumbuhan dan Hasil Kentang. Journal Horticultura. Vol. 24 (1): $49-55$.

Rahman, D. Lasamadi, S.S. Malalantang dan Rustandi. 2013. Pertumbuhan dan Perkembangan Rumput Gajah Dwarf (Pennisetum purpureum cv. Mott) yang DiberiPupuk Organik Hasil Fermentasi EM4. Jurnal Zootek.

Rinsema, 1989. Pupuk dan Pemupukan. Bhratara Karya Aksara. Jakarta

Sinaga, R. 2007. Analisis Model KetahananRumput Gajah dan Nevalensis Akibat Cekaman Kekeringan Berdasarkan Respon Anatomi Akar dan Daun. Jurnal Biologi Sumatera. 2 (1) : 17 20.

Slamet, W., E.D. Purbayatidan C.I. Sutrisno, 2005. Pemanfaatan Limbah Potong Hewan dan Limbah Industri Minuman untuk Kompos. Jurnal Penelitian Pertanian Tropika. 3 (1) : 17 - 26.

Suharlinadan L. Abdullah., 2012. Peningkatan Produktivitas Indigofera sp. Sebagai Pakan Hijauan Berkualitas Tinggi Melalui Aplikasi Pupuk Organik Cair : 1. Produksi Hijauan dan Dampaknya terhadap Kondisi Tanah Pastura. Journal Tumbuhan PakanTropika, Vol. 1 (2): 39 43.

Taufika, R., 2011. Pengujian beberapa Dosis Pupuk Organik Cair terhadap Pertumbuhan dan hasi I Tanaman Wortel (Daucuscarota L.). Jurnal Tanaman Holtikultura, Vol. 8(2):1-10.

Wachjar, A. dan L. Kadarisman (2007). Pengaruh Kombinasi Pupuk Organik Cair dan Pupuk Anorganik serta Frekuaensi Aplikasinya terhadap Pertumbuhan Tanaman Kakao (Theobroma cacao L). Buletin Agronomi. Vol. 35 (3): 212 -216

Wijitphan, S., P. Lorwilai., and C. Arkaseang, 2009. Effects of Plant Spacing on Yields nd Nutritive values of napier Grass (Pennisetum purpureum Schum.) Under Intensive Management of Nitrogen Fertilizer and Irrigation. Pakistan Journal of Nutrition 8(8):1240-1243.

Xiangyang, L., R. Guangxi dan S. Yan., 2011. The Effect of Organic Manure And Chemical Fertilizer on Growth and Development of Stevia RebaudianaBertoni. Energy ProcediaVol 5(2011): $1200-1204$ 